\title{
COINTEGRATION ANALYSIS ON TRADING BEHAVIOR IN FOUR SELECTED ASEAN COUNTRIES BEFORE MONETARY CRISIS
}

\begin{abstract}
R. Budi Prawoto
This paper aims to analyze Indonesian position among the trading behavior in four selected ASEAN countries (according to their import-and-export products) using cointegration analysis. The demands for export and import are estimated before the monetary crisis erupted (1963-1995) using the dynamic OLS (DOLS) method. The Johansen Maximum Likelihood (JML) approach is also employed to compare the results obtained. The results show that foreign income has a significant impact on export demand, suggesting that foreign disturbance in the form of economic activities is likely to be transmitted to these countries. The Marshall Lerner conditions are easilymet for the cases of Malaysia and Thailand (DOLS and JML). For Indonesia and the Philippines, the sum of the price elasticities of export and import demand are less than unity. This can be explained by the J-curve, in which the currency depreciations will first worsen the trade balance before it improves, and it takes a long time to affect the trade balance.
\end{abstract}

Keywords: currency depreciations; dynamic OLS (DOLS); export-import; Indonesia; Johansen maximum likelihood (JML) 
Gadjah Mada International Journal of Business, May - August 2007, Vol. 9, No. 2

\section{Introduction}

The literature has quite extensively dealt with the estimations of price and income elasticities of export and import demand. The existing models mostly use a simple OLS method to estimate the price and income elastic relation of export and import demand. The problem with this time series analysis is that we can not draw general conclusions from the result of a particular time-series analysis as the estimated parameters in the static OLS are subject to bias in small sample since the lagged terms are ignored (see Banerjee, Galbraith, and Hendry 1993). One way to tackle this problem is by using the dynamic OLS method in which lagged and leading values of the first differences of variable I (1) are included.

The Johansen Maximum Likelihood approach can also be used as it provides direct estimates of the cointegrated vectors and allows the testing of the number of cointegrated vectors. However, in practice, the Johansen approach also has a few disadvantages. First, if the sample size is small, the estimates obtained for a cointegrating vector might be undetermined. Second, if the cointegrating vector is not a unique one, there will be an identification problem, and it may be difficult to disentangle economically meaningful cointegrating vectors. As a consequence, a strategy is adopted to use both these approaches, and the results are then compared.
The responsiveness of trade flows to relative price changes is the main concern in formulating an exchange rate policy to correct the trade imbalance. If the sum of export and import demand is greater than unity, it indicates that a depreciation or devaluation will have a favorable effect on the tradebalance as it satisfies the MarshallLerner condition. However, exchange rate policy is always accompanied by other macroeconomic policies (fiscal or monetary policies), as it is difficult to measure the effects of policy without controlling for the others (see Tang 2003). Therefore, the effects of all the policies on trade balance should be combined. In some situations, trade balance worsens before it improves in response to depreciation; this is knows as the $\mathrm{J}$ curve effect which is due to the low price elasticity to demand for exports and imports in the immediate aftermath of an exchange rate change.

The purpose of this paper is to estimate the price and income elasticities of the four selected ASEAN countries demand for exports and imports. Countries selected are based on the characteristics of their export/import products. The study can be justified as follows:

i. It differs from most earlier studies, such as Bond (1985); Cline (1984); Goldstein and Khan (1982); Marquez and McNeilly (1988); Mustacelii (1994); Muscatelli, Stevensen, and Mobtagna (1995a). These studies used static long-run regressions in which the estimated 
Prawoto-Cointegration Analysis on Trading Behavior in Four Asean...

parameters in the static long run OLS are subject to bias in small sample since lagged terms are ignored. This study uses a dynamic OLS to avoid this problem. Estimates taken from the conditional error-correction model are equivalent to full-information maximum likelihood estimates, and are therefore asymptotically normal, allowing for standard inference. On the contrary, for the static regression case, the ratios have non-standard distributions even asymptotically (see Baffes et al. 1999).

ii. Tang (2003) and Mohammad and Tang (2000) have also studied the same phenomenon, however from a different point of view. ${ }^{1}$ These two studies describe the condition of trade after the monetary crisis, while the present study focuses on the condition before the crisis, and tries to examine its underlying factors. By examining the significant trends of trade in four selected ASEAN countries, this study intends to further complement the insights gained from these two studies and portray the background for the development of global trade in ensuing period, and is expected to facilitate any further analysis, especially for the four selected ASEAN countries.

iii. By adopting the cointegration method, the problem of spurious regression is avoided as variables involved in both export and import demands are non-stationary in their levels. The maximum likelihood approach is also employed to confirm results obtained from the dynamic OLS method. However, the Johansen procedure has serious limitations where it deteriorates dramatically in small sample, generating estimates with "fat tails" (frequent outliers). Therefore, results from the dynamic OLS method will be the main focus.

iv. The findings of this study provide empirical evidence suggesting that the exchange rate policy (i.e., Malaysia and Thailand) is effective to correct the trade balance deficit as the Marshall-Lerner conditions is met.

v. For the purpose of this study, data are gathered from the 1995 period onwards. This is necessary to analyze the trading behavior of the four selected ASEAN countries before the crisis. The condition in 1995 showed that the trading behavior was on a stable position with growth tendency. Near 1997, volatility began to surface in the otherwise stable trading condition in Indonesia. The stable condition found in 1995 only lasted for two years until 1997, and was followed by a sharp market decline in the four selected ASEAN countries, especially in Indonesia, making it very difficult to properly shape the policies for ensuing years. The impact of global market and the

\footnotetext{
${ }^{1}$ This has thankfully been pointed out by anonymous reviewers.
} 
policies of developed countries in 1997 were found to be very significant for the selected ASEAN countries.

\section{Literature Review}

The issue of price and income elasticities has received much attention recently. Several methods have been used to estimate price and income elasticities of export and import demand. Studies conducted by Bond (1985), Cline (1984), Goldstein and Khan(1982), Muscatelli(1994, 1995a), Marquez and McNeilly (1998), and O'Neill and Ross (1991) have supported the conventional view, which states that price elasticity of demand for newly industrialized countries' (NICs) exports are small. However, the world's income elasticity of demand for the NIC's exports is significant and high. Conversely, Riedel (1996) have criticized the conventional view, and finds that income elasticity is insignificant, and the price elasticity of export demand are infinite.

Arguments regarding the size of elasticity of export revolve around the issue of normalization. As argued by Riedel (1998), by using the conventional approach to which export volumes are modeled as a demand equation that depends on the domestic price relative to world price and on world income, the price elasticity of demand tends to be low and the income elasticity of demand tend to be very high. Therefore, it is argued that the export demand function should be normal- ized for price rather than for the quantity. Mustacelli(1994) used the PhilipsHansen method to test Riedel's data, and finds that the price elasticity of demand is actuality low and income elasticity is high. Furthermore, by using a more dynamic specification model of demand and supply, the normalization paradox disappears.

For the Malaysian case, a study done by Tang (2003) finds that export and import of Malaysia are cointegrated. Thus, macroeconomic policies are effective to bring export and import into long-run equilibrium. A study done by Mohamad and Tang (2000) examined the long-run relationship between aggregate import and expenditure components of five ASEAN countries. Using the Johansen multivariate cointegration analysis, the use of disaggregating demand variable in its components avoids the possibility of aggregate bias. Their findings show that in the case of Malaysia, the import demand is cointegrated with its determinants, and import demand is elastic with respect to relative prices. The Marshall Lerner condition is met, suggesting that devaluation is effective in correcting balance of payments disequilibrium.

As stated above, the issue of the aggregation level needs to be taken into account. Aggregation across different commodity groups, or different countries, must be well determined. Different groups of commodity can be aggregated only if the patterns of their exports are comparable. Therefore, in this study, ASEAN countries chosen 
Prawoto-Cointegration Analysis on Trading Behavior in Four Asean...

are those with similar trade characteristics and trade directions.

\section{Methods of Estimation}

Theoretical Specification of the Export and Import Functions, the world demand for exports and imports from ASEAN countries are specified in long linear forms as follows:

$$
\begin{aligned}
& \log \mathrm{Q}_{\mathrm{x}} 1 \mathrm{~d}= \mathrm{a}_{0}+\mathrm{a}_{1} \log (\mathrm{Px} / \mathrm{Pw})_{1}+ \\
& \mathrm{a}_{2} \log \mathrm{Yw}_{1}+ \\
& \mathrm{a}_{3} \log \mathrm{Gei}_{1}+\mathrm{ux}_{1} \\
& \mathrm{~A}_{3} \log \mathrm{Gei}_{1}+\mathrm{ux}_{1} \\
& \mathrm{~A}_{1}<0, \mathrm{a}_{2}>0
\end{aligned}
$$

$\log \mathrm{Q}_{\mathrm{mt}}{ }^{\mathrm{d}}=\mathrm{b}_{0}+\mathrm{b}_{1} \log (\mathrm{Pm} / \mathrm{GP})_{1}+$

$$
+\mathrm{b}_{2} \log \mathrm{Yb}_{1}+\mathrm{vm}_{1}
$$

$$
\mathrm{b}_{1}<0, \mathrm{~b}_{2}>0
$$

Where $\mathrm{u}_{\mathrm{x}}, \mathrm{v}_{\mathrm{m}}$, are the error terms, $\mathrm{a}_{0}$ and $\mathrm{b}_{0}$ are the constant terms and:

$\mathrm{Q}_{\mathrm{x}}=$ Export of goods

$\mathrm{Px}=$ Price of exports

$\mathrm{PW}=$ Price of world export

$\mathrm{Yw}=$ Scale variable

$\mathrm{Gci}=$ Export composition index

$\mathrm{Q}_{\mathrm{m}}=$ Import of goods

$\mathrm{Pm}=$ Price of home country imports

$\mathrm{GP}=$ Domestic price level

$\mathrm{Yb}=$ Real income of home country

The model which is referred to as the 'equilibrium' model assumes the simplifying assumption that there are no lags in the system so that the adjust- ment of export and import quantities and prices to their respective equilibrium values is instantaneous. The commonly used log linear functional form is employed instead of the linear one as it implies that the elasticity is constant.

The demand for export (Equation 1 ) is dependent upon the relative price of export with respect to the world price $(\mathrm{Px} / \mathrm{Pw})$, the scale variable $(\mathrm{Yw})$ which captures world demand conditions, and the export composition index (Gei). The price is assumed to be homogenous in the long run so that demand depends only on relative prices and the scale variable. The choice of the scale variable may vary; some authors use (trade weighted) world income as a scale variable [Khan (1987); Aspe and Giavazzi (1982); Marquez and McNeilly (1988)] while others, for example, Muscatelli et al. (1995), use trade weighted imports of the country's exports destination as a scale variable. The coefficients of $a_{1}$ and $a_{2}$ are the price and income elasticities of foreign demand for home country exports, and are expected to be negative and positive, respectively. The export composition index is included in the export demand equation, as the commodity type effects will be implicitly captured by the income and price effects if they are not included in the equation. The coefficient a is expected to be positive.

The demand for import (Equation 2 ) is dependent upon the relative price of import with respect to be general price level $(\mathrm{pm} / \mathrm{GP})$, and the real in- 
come of the home country (Yb). Coefficients $b_{1}$ and $b_{2}$, are expected to be negative and positive, respectively.

The study uses annual data for the period of 1963-1995, specifically before the occurrence of the financial crisis. The description and the computations of variables (i.e, Qx, Qm, Pw, $\mathrm{Yw}$ and Gei) are given in the Appendix.

\section{Integration and Cointegration Tests}

The Dickey-Fuller (DF) and Augmented Dickey-Fuller (ADF) tests are used in this study to test for integration levels. They are both t-tests, and rely on rejecting the hypothesis that the series are a random walk in favor of stationary. By using the ADF and DF tests, the data are tested to see whether all variables are non-stationary. The $\mathrm{DF} / \mathrm{ADF}$ tests for the unit roots for both export and import equations for the ASEAN countries are shown in Table 1 and Table 2.

The Engle-Granger is widely used to estimate the long-run regression. However, the estimated parameters in the static long-run OLS are subject to bias in small sample since lagged terms are ignored (see Banerjee, Galbraith, and Hendry 1993). One way to correct this problem is by including dynamic components (i.e., differences and lagged) to the cointegration (Cuthbertson et al. 1992).
By applying the dynamic OLS (DOLS), the potential of simultaneity bias and small sample bias among regressors is tackled by the inclusion of lagged and leading values of the first differences of the variables I (1) (see Phillips and Loretan 1991 and Saikkonen 1991). There is a trade-off involved with lag length choice in the general time-series regression model; using too few lags can decreases forecast accuracy because valuable information is lost, but adding lags increase estimation uncertainty. The choice of lags must balance the benefits of using additional information against the costs of estimating the additional coefficients.

One way to determine the number of lags to include is to use the Fstatistics to test joint hypotheses that the set the coefficients equal zero. The $\mathrm{BIC}$ and $\mathrm{AIC}$ can be used to estimate the number of lags and variables in the time series. The model with the lowest value of the AIC (or BIC) is the preferred model. The export demand and import demand equations are estimated to include up to $j= \pm 3$ leads and lags. Insignificant leads and lags will be dropped. The robust standard errors facilitate valid inferences to be made upon the coefficients of the variables entering as regressors. Based on the dynamic OLS method, the long-run export demand and import demand equations are as follows: 
Prawoto-Cointegration Analysis on Trading Behavior in Four Asean...

Table 1. The DF/ADF Test for Unit Roots (Export)

\begin{tabular}{|c|c|c|c|c|}
\hline \multirow{2}{*}{$\begin{array}{l}\text { Variables } \\
\text { Country }\end{array}$} & \multicolumn{2}{|c|}{ Level } & \multicolumn{2}{|c|}{$1^{\text {st }}$ Differences } \\
\hline & DF & ADF (1) & DF & ADF (1) \\
\hline \multicolumn{5}{|l|}{ Indonesia } \\
\hline $\begin{array}{l}\mathrm{Q}_{\mathrm{x}}^{\mathrm{d}} \\
\mathrm{Px} / \mathrm{Pw} \\
\mathrm{Yw} \\
\mathrm{Gci}\end{array}$ & $\begin{array}{l}-0.7810 \\
-0.8934 \\
-1.4669 \\
-3.0363\end{array}$ & $\begin{array}{l}-3.2414 \\
-1.3512 \\
-2.1276 \\
-3.2699\end{array}$ & $\begin{array}{l}-4.4122 \\
-3.7388 \\
-3.8660 \\
-7.3673\end{array}$ & $\begin{array}{l}-3.4693 \\
-2.7769 \\
-2.8568 \\
-7.3029\end{array}$ \\
\hline \multicolumn{5}{|l|}{ Malaysia } \\
\hline $\begin{array}{l}\mathrm{Q}_{\mathrm{x}}^{\mathrm{d}} \\
\mathrm{Px} / \mathrm{Pw} \\
\mathrm{Yw} \\
\mathrm{Gci}\end{array}$ & $\begin{array}{l}-1.4475 \\
-1.8852 \\
-3.0719 \\
-2.2639\end{array}$ & $\begin{array}{l}-1.3313 \\
-2.3029 \\
-3.1144 \\
-1.9793\end{array}$ & $\begin{array}{l}-5.3404 \\
-4.5316 \\
-6.1905 \\
-6.2593\end{array}$ & $\begin{array}{l}-4.6957 \\
-4.9740 \\
-4.9352 \\
-8.5296\end{array}$ \\
\hline \multicolumn{5}{|l|}{ Philippines } \\
\hline $\begin{array}{l}\mathrm{Q}_{\mathrm{x}}^{\mathrm{d}} \\
\mathrm{Px} / \mathrm{Pw} \\
\mathrm{Yw} \\
\mathrm{Gci}\end{array}$ & $\begin{array}{l}-1.7027 \\
-1.3380 \\
-3.8837 \\
-3.2397\end{array}$ & $\begin{array}{l}-2.2053 \\
-1.8139 \\
-2.9312 \\
-2.5257\end{array}$ & $\begin{array}{l}-4.0105 \\
-3.9623 \\
-7.5241 \\
-7.9373\end{array}$ & $\begin{array}{l}-3.2116 \\
-3.7427 \\
-5.4290 \\
-5.4891\end{array}$ \\
\hline \multicolumn{5}{|l|}{ Thailand } \\
\hline $\begin{array}{l}\mathrm{Q}_{\mathrm{x}}{ }^{\mathrm{d}} \\
\mathrm{Px} / \mathrm{Pw} \\
\mathrm{Yw} \\
\mathrm{Gci}\end{array}$ & $\begin{array}{l}-1.7780 \\
-1.6544 \\
-3.2107 \\
-2.8161\end{array}$ & $\begin{array}{l}-1.7399 \\
-1.9116 \\
-2.1688 \\
-3.0014\end{array}$ & $\begin{array}{l}-5.1106 \\
-5.1296 \\
-6.7846 \\
-4.8638\end{array}$ & $\begin{array}{l}-3.5113 \\
-5.3150 \\
-3.5157 \\
-4.9256\end{array}$ \\
\hline
\end{tabular}

Notes: All variables are in $\log$

The variables are as follows; total export index $\left(\mathrm{Q}_{\mathrm{x}}{ }^{\mathrm{d}}\right)$, relative price $(\mathrm{Px} / \mathrm{Pw})$, a weighted (by the share of exports) average of the trade partners GDP (Yw) and export composition index (Gci). ADF critical value for level is -3.5468 and ADF critical value for $1^{\text {st }}$ difference is 3.5514 .

All econometric computations have been carried out by Microfit 4.0 Version (see Pesaran \& Pesaran, (1997)). In most of the cases, the intercept term are included in the relevant DF and $\mathrm{ADF}$ equations. An augmentation of one seems sufficient to secure lack of autocorrelation of the error terms, however, in some cases, no augmentation was necessary. 
Gadjah Mada International Journal of Business, May - August 2007, Vol. 9, No. 2

Table 2. The DF/ADF Test for Unit Roots (Import)

\begin{tabular}{|c|c|c|c|c|}
\hline \multirow{2}{*}{$\begin{array}{l}\text { Variables } \\
\text { Country }\end{array}$} & \multicolumn{2}{|c|}{ Level } & \multicolumn{2}{|c|}{$1^{\text {st }}$ Differences } \\
\hline & DF & ADF (1) & DF & ADF (1) \\
\hline \multicolumn{5}{|l|}{ Indonesia } \\
\hline $\mathrm{Q}^{\mathrm{md}}$ & -1.7411 & -2.5599 & -3.1280 & -3.6050 \\
\hline $\mathrm{Pm} / \mathrm{Pp}$ & -3.1421 & -1.2691 & -.1279 & -9.3000 \\
\hline $\mathrm{Yb}$ & -1.3572 & -1.8071 & -2.9900 & -3.6700 \\
\hline \multicolumn{5}{|l|}{ Malaysia } \\
\hline $\mathrm{Q}^{\mathrm{md}}$ & -0.5268 & -0.5636 & -4.9922 & -4.9714 \\
\hline $\mathrm{Pm} / \mathrm{Pp}$ & -1.3794 & -1.9296 & -4.2710 & -3.3686 \\
\hline $\mathrm{Yb}$ & -1.4940 & -2.0916 & -3.9630 & -3.9443 \\
\hline \multicolumn{5}{|l|}{ Philippines } \\
\hline $\mathrm{Q}^{\mathrm{md}}$ & -0.8426 & -0.7381 & -8.4897 & -7.3153 \\
\hline $\mathrm{Pm} / \mathrm{Pp}$ & -0.6882 & -0.7704 & -3.6138 & -3.8170 \\
\hline $\mathrm{Yb}$ & -1.4304 & -1.8214 & -3.8774 & -3.2588 \\
\hline \multicolumn{5}{|l|}{ Thailand } \\
\hline $\mathrm{Q}^{\mathrm{md}}$ & -0.7757 & -1.5146 & -3.8270 & -3.9360 \\
\hline $\mathrm{Pm} / \mathrm{Pp}$ & -1.0663 & -1.8596 & -3.4775 & -3.2422 \\
\hline $\mathrm{Yb}$ & -1.6134 & -2.5190 & -3.8321 & -3.7318 \\
\hline
\end{tabular}

Notes: All variables are in $\log$

The variables are as follows; total import index $\left(\mathrm{Q}_{\mathrm{m}}{ }^{\mathrm{d}}\right)$, relative price $(\mathrm{Pm} / \mathrm{Gp})$ and the real income $(\mathrm{Yb})$. ADF critical value for level is -3.5468 and $\mathrm{ADF}$ critical value for $1^{\text {st }}$ difference is -3.5514 .

All econometric computations have been carried out by Microfit 4.0 Version (see Pesaran \& Pesaran, (1997). In most of the cases, the intercept term are included in by relevant DF and ADF equations. An augmentation of one seems on sufficient secure lack of autocorrelation in the error terms, however, in some cases, no augmentation was necessary.

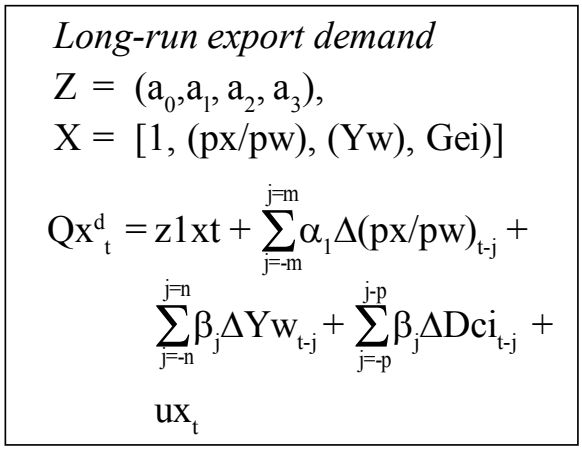

$$
\begin{aligned}
& \text { Long-run import demand } \\
& \mathrm{Z}=(\mathrm{b} 0, \mathrm{~b} 1, \mathrm{~b} 2), \\
& \mathrm{X}=[1,(\mathrm{pm} / \mathrm{gp}),(\mathrm{Yb})] \\
& \text { Qmd } 1=\mathrm{z} 1 \mathrm{xt}+ \\
& \text { Qmd } 1=\mathrm{z} 1 \mathrm{xt}+\sum_{\mathrm{j}=\mathrm{n}}^{\mathrm{j}=\mathrm{n}} \lambda_{\mathrm{j}} \Delta(\mathrm{pm} / \mathrm{gp})_{\mathrm{t}-\mathrm{j}}+ \\
& \sum_{\mathrm{j}=\mathrm{n}}^{\mathrm{j}=\mathrm{n}} \eta_{\mathrm{j}} \Delta \mathrm{Yb}_{\mathrm{t}-\mathrm{j}}+\mathrm{vm}_{\mathrm{t}}
\end{aligned}
$$


Prawoto-Cointegration Analysis on Trading Behavior in Four Asean...

\section{Results}

\section{The OLS Residual-Based Test}

Table 3 reports the ADF residual based test results for cointegration for the export demand equations. Table 2 , in Charemza and Deadman (1992), provides approximate critical values for the cointegration test for 30 observations with $m=3$ at 5 precent level of significance, which are -3.71 (lower bound) and -3.50 (upper bound). The null hypothesis of no cointegration is rejected if the value is below -3.71 ; and is not rejected if the value is above -3.50 . Values between -3.71 and 3.50 lie in the inconclusive region. Based on the test statistics, the null hypothesis of no cointegration for the corresponding residual obtained from the long-run export demand equation can be rejected at 5 percent level of significance (i.e., Malaysia and Indonesia). However, for Thailand's long run export demand equation, the corre- sponding residual obtained from the equation is in the "inconclusive region" at 5 percent level of significance although the null of no cointegration can be rejected at 10 percent level of significance. For the case of the Philippines, the null of cointegration can also be rejected at 10 percent level of significance.

For the import demand equation, the null hypothesis of no cointegration at 5 percent level of significance is rejected (i.e., Malaysia and Indonesia). For the Philippines, the null hypothesis of no cointegration at 10 percent level of significance is rejected. For Thailand, the corresponding residual obtained from the equation is slightly below the upper bound critical value. However, it is assumed that all variables are cointegrated as the standard tests are over-cautious in rejection of the null hypothesis of no cointegration. This emphasizes type I error whereas type 2 error, that is, failing to reject the null when it is false,

Table 3. ADF Residual-based Test for Cointegration The Long-run Export Equations

\begin{tabular}{|c|c|c|c|c|c|c|}
\hline & \multicolumn{2}{|c|}{ Test Statistics } & \multicolumn{4}{|c|}{ Critical Value* } \\
\hline & \multirow[t]{2}{*}{ DF } & \multirow[t]{2}{*}{ ADF (1) } & \multicolumn{2}{|c|}{$5 \%$} & \multicolumn{2}{|c|}{$10 \%$} \\
\hline & & & $\mathbf{U}$ & $\mathbf{L}$ & $\mathbf{U}$ & $\mathbf{L}$ \\
\hline Indonesia & -4.24 & -4.33 & -3.50 & -3.71 & -3.16 & -3.33 \\
\hline Malaysia & -2.67 & -3.90 & -3.50 & -3.71 & -3.16 & -3.33 \\
\hline Thailand & -3.58 & -3.64 & -3.50 & -3.71 & -3.16 & -3.33 \\
\hline Philippines & -3.62 & -3.27 & -3.50 & -3.71 & -3.16 & -3.33 \\
\hline
\end{tabular}

Notes: *The critical values are obtained from Charemza and Deadman (1992) with 30 numbers of observation and $\mathrm{m}=3$. One also can refer to other sources values tables i.e MacKinnon (1991), Engle-Granger (1987), Table 2 and Table 3, Engle and Yoo (1987) 
Gadjah Mada International Journal of Business, May - August 2007, Vol. 9, No. 2

Table 4.ADF Residual-based Test for Cointegration

The Long-run Import Equations

\begin{tabular}{|c|c|c|c|c|c|c|}
\hline & \multicolumn{2}{|c|}{ Test Statistics } & \multicolumn{4}{|c|}{ Critical Value* } \\
\hline & \multirow[t]{2}{*}{ DF } & \multirow[t]{2}{*}{ ADF (1) } & \multicolumn{2}{|c|}{$5 \%$} & \multicolumn{2}{|c|}{$10 \%$} \\
\hline & & & $\mathbf{U}$ & $\mathbf{L}$ & $\mathbf{U}$ & $\mathbf{L}$ \\
\hline Indonesia & -2.99 & -3.69 & -3.15 & -3.31 & -2.80 & -2.96 \\
\hline Malaysia & -2.13 & -3.29 & -3.15 & -3.31 & -2.80 & -2.96 \\
\hline Thailand & -1.79 & -2.34 & -3.15 & -3.31 & -2.80 & -2.96 \\
\hline Philippines & -1.89 & -2.80 & -3.50 & -3.31 & -2.80 & -2.96 \\
\hline
\end{tabular}

Notes: ${ }^{*}$ The critical values are obtained from Charemza and Deadman (1992) with 30 numbers of observation and $m=3$. One also can refer to other sources values tables i.e. MacKinnon (1991), Engle-Granger (1987), Tables II and III), Engle and Yoo (1987)

is more important here. Consequently, we should be generous in interpreting the statistics. Accordingly, all variables involved in the equations are cointegrated, or, in short, the long-run relationships among variables are not spurious. This is shown in Table 4.

The CRDW is used to see whether all the variables are cointegrated. Engle and Yoo (1987) provide a CRDW critical value for $n=50$; the two-variables case is 0.78 at 5 percent level of significance, and 0.69 at 10 percent level of significance. The CRDW for Malaysia's export demand is 1.42 , which is larger that the 5 percent critical value; therefore, the null of no cointegration is rejected.

\section{The DOLS}

Table 5 show the dynamic OLS parameter estimates of the long-run export demand with all variables in levels, along with their approximate asymptotic standard errors for all coun- tries. Based on the results obtained, for most cases, both the long-run income and price elasticities have correct signs as anticipated. The long-run income elasticities vary from 0.15 (Philippines) to 1.37 (Thailand). In all cases, they are significant. The long-run priceelasticities vary from -0.26 (Indonesia) to -2.41 (Thailand). As the export composition index is only significant for Malaysia, it is dropped for the other three countries.

The price elasticity in the import demand equations are correctly signed and are significant. The long-run price elasticities of import demand vary from -0.27 (Philippines) to -1.50 (Thailand). The income variable is also correctly signed and significant for all cases. The long-run income elasticities vary from 0.35 (Philippines) to 0.90 (Malaysia). Table 6 reports the results for import demand equations that show the correct signs for income and price elasticities. 
Prawoto-Cointegration Analysis on Trading Behavior in Four Asean...

Table 5. The DOLS Export Demand Equations (long run)

\begin{tabular}{|c|c|c|c|c|c|}
\hline Country & $\mathbf{P x} / \mathbf{P w}$ & Yw & Gci & ser & $\mathbf{R}^{2}$ \\
\hline Indonesia & $\begin{array}{c}-0.26 \\
(0.1076)\end{array}$ & $\begin{array}{c}0.53 \\
(0.0488)\end{array}$ & - & 0.12 & 0.96 \\
\hline Malaysia & $\begin{array}{c}-0.35 \\
(0.0646)\end{array}$ & $\begin{array}{c}0.21 \\
(0.0621)\end{array}$ & $\begin{array}{c}1.69 \\
(0.1715)\end{array}$ & 0.05 & 0.99 \\
\hline Thailand & $\begin{array}{c}-2.41 \\
(0.3911)\end{array}$ & $\begin{array}{c}1.37 \\
(0.0723)\end{array}$ & - & 0.12 & 0.98 \\
\hline Philippines & $\begin{array}{c}-0.32 \\
(0.1273)\end{array}$ & $\begin{array}{c}0.15 \\
(0.0656)\end{array}$ & - & 0.12 & 0.87 \\
\hline
\end{tabular}

Notes: values in parentheses is standard errors

Table 6. The DOLS Import Demand Equations (long run)

\begin{tabular}{|c|c|c|c|c|}
\hline Country & Pm/Gp & $\mathbf{Y b}$ & ser & $\mathbf{R}^{2}$ \\
\hline Indonesia & $\begin{array}{c}-0.41 \\
(0.1974)\end{array}$ & $\begin{array}{c}0.46 \\
(0.0996)\end{array}$ & 0.14 & 0.96 \\
\hline Malaysia & $\begin{array}{c}-1.24 \\
(0.858)\end{array}$ & $\begin{array}{c}0.90 \\
(0.1169)\end{array}$ & 0.24 & 0.93 \\
\hline Thailand & $\begin{array}{c}-1.50 \\
(0.1505)\end{array}$ & $\begin{array}{c}0.70 \\
(0.0215)\end{array}$ & 0.09 & 0.98 \\
\hline Philippines & $\begin{array}{c}-0.27 \\
(0.0898)\end{array}$ & $\begin{array}{c}0.35 \\
(0.069)\end{array}$ & 0.15 & 0.88 \\
\hline
\end{tabular}

Notes: values in parentheses is standard errors

The Johansen Maximum Likelihood Approach By applying the Johansen Maximum Likelihood approach (see Johansen 1991), cointegration is found for all countries. Information from the unrestricted VAR model is used to determine the order of the VAR. The Schwarz Bayesian Criterion (SBC) and the Akaike Information Criterion are utilized to determine the length of optimal lag. The longlikelihood ratio statistics are then used for testing zero restrictions on the coefficients of a subset of deterministic/ exogenous variable; the presence of an intercept could not be rejected.

The results of the JohansenJuselius cointegration tests for both exports and imports are shown in Tables 7 and 8 . The trace statistics and the eigenvalue (maximum) tests show that there exists only one cointegrating relationship. The Johansen Likelihood ratio statistics are used to determine 
Gadjah Mada International Journal of Business, May - August 2007, Vol. 9, No. 2

Table 7. John Johansen Maximum Likelihood Cointegration Test - Exports

Indonesia: Cointegration with Unrestricted Intercepts and No Trends in the $\operatorname{VAR}(k=1)$

\begin{tabular}{|c|c|c|c|c|c|c|}
\hline \multirow[b]{2}{*}{ Eigenvalue } & \multirow[b]{2}{*}{$\lambda_{\max }$} & \multirow[b]{2}{*}{$\lambda_{\text {Trace }}$} & \multirow[b]{2}{*}{$\mathbf{H}_{0}=\mathbf{r}$} & \multirow[b]{2}{*}{$H_{D}=P-r$} & \multicolumn{2}{|c|}{ Critical Value } \\
\hline & & & & & $95 \%$ L-max & $95 \%$ trace \\
\hline 60 & $29.9^{\prime}$ & 53.9 & 0 & 1 & 27.4 & 4880 \\
\hline 0.43334 & 18.1758 & 23.9985 & 1 & 2 & 21.12 & 21.54 \\
\hline 0.16377 & 5.7233 & 5.8228 & 2 & 3 & 14.88 & 17.86 \\
\hline 0.031024 & 0.099431 & 0.099431 & 3 & 4 & 8.07 & 8.07 \\
\hline
\end{tabular}

Malaysia: Cointegration with Unrestricted Intercepts and No Trend in the VAR $(k=2)$

\begin{tabular}{|c|c|c|c|c|c|c|}
\hline \multirow{2}{*}{ Eigenvalue } & \multirow{2}{*}{$\lambda_{\max }$} & \multirow{2}{*}{$\lambda_{\text {Trace }}$} & \multirow{2}{*}{$H_{0}=r$} & \multirow{2}{*}{$H_{D}=P-r$} & \multicolumn{2}{|c|}{ Critical Value } \\
\hline & & & & & 95\% L-max & $95 \%$ trace \\
\hline 70729 & 39.31401 & 5.1817 & 0 & 1 & 27.42 & 48.80 \\
\hline 0.26291 & 9.7613 & 15.8678 & 1 & 2 & 21.12 & 31.54 \\
\hline 0.15325 & 5.3231 & 6.1064 & 2 & 3 & 14.88 & 17.86 \\
\hline 0.0241842 & 0.78339 & 0.78339 & 3 & 4 & 8.07 & 8.07 \\
\hline
\end{tabular}

Philippines: Cointegration with Unrestricted Intercepts and No Trend in the $\operatorname{VAR}(k=1)$

\begin{tabular}{|c|c|c|c|c|c|c|}
\hline \multirow[b]{2}{*}{ Eigenvalue } & \multirow[b]{2}{*}{$\lambda_{\text {max }}$} & \multirow[b]{2}{*}{$\lambda_{\text {Trace }}$} & \multirow[b]{2}{*}{$\mathrm{H}_{0}=\mathrm{r}$} & \multirow[b]{2}{*}{$H_{D}=P-r$} & \multicolumn{2}{|c|}{ Critical Value } \\
\hline & & & & & 95\% L-max & $95 \%$ trace \\
\hline 0.51959 & 21.2602 & 35.7503 & 0 & 1 & 27.42 & 45.70 \\
\hline 0.25767 & 8.6410 & 14.4902 & 1 & 2 & 21.12 & 28.78 \\
\hline 0.16226 & 5.4345 & 5.8472 & 2 & 3 & 14.88 & 15.75 \\
\hline 0.024346 & 0.71476 & 0.71476 & 3 & 4 & 8.07 & 8.07 \\
\hline
\end{tabular}

Thailand: Cointegration with Unrestricted Intercepts and No Trend in the VAR $(k=2)$

\begin{tabular}{|c|c|c|c|c|c|c|}
\hline \multirow{2}{*}{ Eigenvalue } & \multirow{2}{*}{$\lambda_{\max }$} & \multirow{2}{*}{$\lambda_{\text {Trace }}$} & \multirow{2}{*}{$\mathbf{H}_{0}=r$} & \multirow{2}{*}{$H_{D}=P-r$} & \multicolumn{2}{|c|}{ Critical Value } \\
\hline & & & & & 95\% L-max & $95 \%$ trace \\
\hline 0.65517 & 33.0058 & 39.6372 & 0 & 1 & 21.12 & 31.54 \\
\hline 0.17991 & 6.1485 & 6.6315 & 1 & 2 & 14.88 & 17.86 \\
\hline 0.015457 & 0.48291 & 0.48291 & 2 & 3 & 8.07 & 8.07 \\
\hline
\end{tabular}

Notes: critical values for ${ }_{\text {max }}$ and ${ }_{\text {trace }}$ are from Microfit. 
Prawoto-Cointegration Analysis on Trading Behavior in Four Asean...

Table 8. John Johansen Maximum Likelihood Cointegration Test - Imports

Indonesia: Cointegration with Unrestricted Intercepts and No Trends in the $\operatorname{VAR}(k=2)$

\begin{tabular}{|c|c|c|c|c|c|c|}
\hline \multirow[b]{2}{*}{ Eigenvalue } & \multirow[b]{2}{*}{$\lambda_{\max }$} & \multirow[b]{2}{*}{$\lambda_{\text {Trace }}$} & \multirow[b]{2}{*}{$H_{0}=r$} & \multirow[b]{2}{*}{$H_{D}=P-r$} & \multicolumn{2}{|c|}{ Critical Value } \\
\hline & & & & & 90\% L-max & $90 \%$ trace \\
\hline 0.48118 & 17.72 & 27.99 & 0 & 1 & 19.02 & 28.78 \\
\hline 0.28714 & 9.14 & 10.28 & 1 & 2 & 12.99 & 15.75 \\
\hline 0.041468 & 1.14 & 1.14 & 2 & 3 & 6.50 & 6.5 \\
\hline
\end{tabular}

Malaysia: Cointegration with Unrestricted Intercepts and No Trend in the $\operatorname{VAR}(k=2)$

\begin{tabular}{|c|c|c|c|c|c|c|}
\hline \multirow[b]{2}{*}{ Eigenvalue } & \multirow[b]{2}{*}{$\lambda_{\max }$} & \multirow[b]{2}{*}{$\lambda_{\text {Trace }}$} & \multirow[b]{2}{*}{$H_{0}=r$} & \multirow[b]{2}{*}{$H_{D}=P-r$} & \multicolumn{2}{|c|}{ Critical Value } \\
\hline & & & & & $90 \%$ L-max & $90 \%$ trace \\
\hline 0.51084 & 22.17 & 27.83 & 0 & 1 & 19.02 & 28.78 \\
\hline 0.15299 & 5.14 & 5.67 & 1 & 2 & 12.98 & 15.75 \\
\hline 0.016594 & 0.52 & 0.52 & 2 & 3 & 6.5 & 6.5 \\
\hline
\end{tabular}

Philippines: Cointegration with Unrestricted Intercepts and No Trend in the $\operatorname{VAR}(k=2)$

\begin{tabular}{|c|c|c|c|c|c|c|}
\hline \multirow[b]{2}{*}{ Eigenvalue } & \multirow[b]{2}{*}{$\lambda_{\max }$} & \multirow[b]{2}{*}{$\lambda_{\text {Trace }}$} & \multirow[b]{2}{*}{$H_{0}=r$} & \multirow[b]{2}{*}{$H_{D}=P-r$} & \multicolumn{2}{|c|}{ Critical Value } \\
\hline & & & & & $90 \%$ L-max & $90 \%$ trace \\
\hline 0.46026 & 18.50 & 28.30 & 0 & 1 & 19.02 & 28.78 \\
\hline 0.20704 & 6.96 & 9.80 & 1 & 2 & 12.98 & 15.75 \\
\hline 0.090358 & 2.84 & 2.84 & 2 & 3 & 6.50 & 6.5 \\
\hline
\end{tabular}

Thailand: Cointegration with Unrestricted Intercepts and No Trend in the VAR $(k=2)$

\begin{tabular}{|c|c|c|c|c|c|c|}
\hline \multirow[b]{2}{*}{ Eigenvalue } & \multirow[b]{2}{*}{$\lambda_{\max }$} & \multirow[b]{2}{*}{$\lambda_{\text {Trace }}$} & \multirow[b]{2}{*}{$\mathbf{H}_{0}=\mathbf{r}$} & \multirow[b]{2}{*}{$H_{D}=\mathbf{P}-\mathbf{r}$} & \multicolumn{2}{|c|}{ Critical Value } \\
\hline & & & & & $90 \%$ L-max & $90 \%$ trace \\
\hline 0.62767 & 29.64 & 31.63 & 0 & 1 & 19.02 & 28.78 \\
\hline 0.06386 & 1.98 & 1.99 & 1 & 2 & 12.98 & 15.75 \\
\hline $0.3434 \mathrm{E}-3$ & 0.0103 & 0.010304 & 2 & 3 & 6.50 & 6.5 \\
\hline
\end{tabular}

Notes: critical values for ${ }_{\text {max }}$ and ${ }_{\text {trace }}$ are from Microfit. 
Gadjah Mada International Journal of Business, May - August 2007, Vol. 9, No. 2

the number of cointegrating vectors, $r$. Both the maximal eigenvalue and the trace test are used, which examine the null hypothesis of cointegrating vectors for $r=0$, followed by $r \leq 2$.

For export demand equation, in most cases, the maximal eigenvalue test $\left(\lambda_{\max }\right.$ test) indicates that the null hypothesis of zero cointegrating vectors is rejected at 95 percent critical value, except for the case of the Philip- pines (see Pesaran and Pesaran 1997). The trace test confirms that there is only one cointegrating relationship among the variables for all countries except for the Philippines. The choice of the number of cointegrating relations harnesses model selection criteria, using both the Akaike Information Criteria (AIC) and the Hannan-Quinn Criteria (HQC), to select one cointegrating relationship.

Table 9. Result from the DOLS and the Johansen VAR Approaches

\begin{tabular}{|c|c|c|c|c|c|c|}
\hline \multirow[t]{2}{*}{ Country } & \multirow[t]{2}{*}{ Variables } & \multicolumn{2}{|c|}{ Exports } & \multirow[t]{2}{*}{ Variables } & \multicolumn{2}{|c|}{ Imports } \\
\hline & & E-G & Johansen & & E-G & Johannes \\
\hline \multirow[t]{3}{*}{ Indonesia } & & & & & & \\
\hline & $(\mathbf{p x} / \mathbf{p w})$ & $\begin{array}{c}-0.26 \\
(0.1076)\end{array}$ & $\begin{array}{l}-0.30 \\
(0.104)\end{array}$ & $(\mathrm{pm} / \mathrm{gp})$ & $\begin{array}{c}-0.41 \\
(0.1974)\end{array}$ & $\begin{array}{c}-0.51 \\
(0.213)\end{array}$ \\
\hline & Yw & $\begin{array}{c}0.53 \\
(0.0488)\end{array}$ & $\begin{array}{c}0.67 \\
(0.051)\end{array}$ & $\mathbf{Y b}$ & $\begin{array}{c}0.46 \\
(0.0996)\end{array}$ & $\begin{array}{c}0.42 \\
(0.121)\end{array}$ \\
\hline \multirow[t]{3}{*}{ Malaysia } & $(\mathbf{p x} / \mathbf{p w})$ & $\begin{array}{c}-0.35 \\
(0.0646)\end{array}$ & $\begin{array}{l}-0.35 \\
(0.056)\end{array}$ & (pm/gp) & $\begin{array}{c}-1.24 \\
(0.858)\end{array}$ & $\begin{array}{c}-2.19 \\
(0.734)\end{array}$ \\
\hline & Yw & $\begin{array}{c}0.21 \\
(0.0621)\end{array}$ & $\begin{array}{c}0.20 \\
(0.053)\end{array}$ & $\mathbf{Y b}$ & $\begin{array}{l}(0.90) \\
(0.1169)\end{array}$ & $\begin{array}{c}1.02 \\
(0.096)\end{array}$ \\
\hline & Gci & $\begin{array}{c}1.69 \\
(0.1715)\end{array}$ & $\begin{array}{c}1.70 \\
(0.1473\end{array}$ & & & \\
\hline \multirow[t]{2}{*}{ Philippines } & $(\mathbf{p x} / \mathbf{p w})$ & $\begin{array}{c}-0.32 \\
(0.1273)\end{array}$ & $\begin{array}{l}-0.25 \\
(0.186)\end{array}$ & (pm/gp) & $\begin{array}{c}-0.27 \\
(0.0898)\end{array}$ & $\begin{array}{l}-1.34 \\
(0.741)\end{array}$ \\
\hline & Yw & $\begin{array}{c}0.15 \\
(0.0656)\end{array}$ & $\begin{array}{c}0.17 \\
(0.061)\end{array}$ & $\mathbf{Y b}$ & $\begin{array}{c}0.35 \\
(0.069)\end{array}$ & $\begin{array}{c}0.99 \\
(0.759)\end{array}$ \\
\hline \multirow[t]{2}{*}{ Thailand } & (px/pw) & $\begin{array}{c}-2.41 \\
(0.3911)\end{array}$ & $\begin{array}{l}-2.69 \\
(0.510)\end{array}$ & (pm/gp) & $\begin{array}{c}-1.50 \\
(0.1505)\end{array}$ & $\begin{array}{l}-1.75 \\
(0.196)\end{array}$ \\
\hline & Yw & $\begin{array}{c}1.37 \\
(0.0723)\end{array}$ & $\begin{array}{c}1.43 \\
(0.096)\end{array}$ & $\mathbf{Y b}$ & $\begin{array}{c}0.70 \\
(0.0215)\end{array}$ & $\begin{array}{c}0.74 \\
(0.026)\end{array}$ \\
\hline
\end{tabular}

Notes: values in parenthesis are standard errors 
Prawoto-Cointegration Analysis on Trading Behavior in Four Asean...

For the import demand equation, the maximal eigenvalue and the trace tests indicate that that the null hypothesis of zero cointegrating vectors is rejected at 90 percent critical value, except for the case of the Philippines and Indonesia. Nevertheless, based on the choice of the number of cointegrating relations using model selection criteria, the Schwarz Bayesian Criteria (SBC) selects one cointegrating relationship for both the Philippines and Indonesia. The estimation of the normalized cointegrating vector is then obtained as the existence of the relationship among the variables is accepted. This is shown in Table 9.

For most of the cases, the price and income elasticities of export demand have the correct signs. For the Malaysian case, the long-run price and income elasticities are -0.35 and 0.20 , respectively. They are both statistically significant. The export composition index also has the predicted sign and is also significant with the value of 1.71. For the Indonesian case, the longrun price and income elasticities are 0.3 and 0.67 , respectively, and both are statistically significant. For the case of Thailand, the price and income elasticities have the predicted signs, and both are significant. The long-run price elasticity is -2.69 whereas the longrun income elasticity is 1.43 . For the Philippines, the long-run price elasticity is -0.25 while the long-run income elasticity is 0.17 . They both have the correct signs and significant. A restriction is imposed on the export composition index (GCI) that $a 4=0$. For the
Malaysian case, the $x^{2}$ is statistically significant; therefore, the null hypothesis of no relationship between the export demand and the export composition index is rejected. For the import demand equations, in all cases, the price and income elasticities all have the correct signs and are significant (see Table 9). There results suggest that both relative price and real income are crucial in determining the import demand.

\section{Conclusions and Policy Implications}

This paper provides estimations of price and income elasticities of export and impor demand based on the situation pre-monetary crisis in 1998 , using both dynamic OLS and Johansen MaximumLikelihood approaches. The cointegration analysis is employed to ensure that regressions are not spurious. Results show that both the price and income elasticities of export and import demand have correct signs as anticipated, and are significant. The elasticity of export demand for most countries is expected, as the bulk of there countries' exports are in the form of strategic raw materials used for industrial purposes.

Different estimates of the price elasticity of export demand function leads to different implications for trade policies. As argued by Athukorala and Riedel (1990), if price elasticity is really low, then standard trade theory would suggest that policymakers in developing countries advocate export 
taxes in place of export promotion. However, liberalization of trade can cause a high improvement in the export growth rates in developing countries, such as the Turkish experience in the 1980s.

There are also implications for (real) exchange rate of cost competitiveness policy. Suppose that the price elasticity of demand is indeed low, one would expect a policy of allowing a real depreciation to generate a rather small expansion of the varieties produced in ASEAN countries. However, lower wage would attract producers to the ASEAN countries, thereby boosting supply and demand at the same time. Hence, a real depreciation policy should not be seen as a ways to cheapen supply which will attract purchasers.

Based on the results obtained, one can observe that foreign income is a significant variable in the export demand equation, suggesting that foreign disturbance in the form of fluctuation in foreign economic activities is likely to be transmitted to those countries. The Marshall-Lerner conditions are met for Malaysia and Thailand as the sum of their price elasticities of export and import demand are greater than unity (both DOLS and Johansen Maximum Likelihood approaches). It means that appreciations (depreciations) in exchange rates can worsen (improve) the current income in a period of one year. For the case of the Philippines and Indonesia, however, the sum of the price elasticities of export and import are less than unity. This can be explained by the J-curve, in which export and import demands tend to be relatively inelastic due to the existing depreciation. The lagged Jcurve also shows that it will first worsen the trade balance before it improves, and it takes time to affect the current account. As mentioned earlier, the exchange rate policy is always accompanied by other macroeconomic policies, as it is difficult to assess the effects of one policy without controlling for the others.

Data are gathered from various issues before Indonesia monetary crisis to analyze the economic situations and the effectiveness of the exportimport activities to develop Indonesian trade and policy making postmonetary crisis.

\section{References}

Aspe, P., and F. Giavazzi. 1982. The short run behavior of price and output in the exportable sector: The case of German machinery. Journal of International Economics 12: 83-93.

Athukorala, P., and J. Riedel. 1996. Modelling NIE exports, aggregation, qualitative, restrictive, restrictions and choice of econometric methodology. Journal of Development Studies 33: 81-98. 
Prawoto-Cointegration Analysis on Trading Behavior in Four Asean...

Baffes, J., I. A. Elbadawi, and S. A. O’ Connell. 1999. Single-equation estimation of the equilibrium real exchange rate. In Hinkle, Lawrence E., and Peter, J. Motiel: Exchange Rate Misalignment: Concept and Measurement for Developing Countries. Oxford: Oxford University Press.

Banerjee, A., J. Galbraith, and D. Hendry. 1993. Cointegration and the Econometric Analysis of Non-stationary Data. Oxford: Oxfrod University Press.

Bond, M. 1985. Export demand and supply for group of non-oil developing countries. IMF Staff Papers 32: 56-77.

Cline, W. R. 1984. Internasional Debt Systemic Risk and Policy Response. Mass: Institute for Internasional Economics. MIT Press: Cambridge.

Charemza, W. W., and D. F. Demand. 1992. New Directions in Econometric Practice: General to Specific Modeling, Cointegration and Vector Auto Regression. Aldershot: Edward Elgar.

Cuthbertson, K., S. G. Hall, and M. P. Taylor. 1992. Applied Econometric Techniques. New York: Philip Allan.

Engle, R. F., and B. S. 1987. Forecasting and testing in cointegrated systems. Journal of Econometrics 35: 143-159.

Engle, R. F., and C. W. J. Granger. 1987). Cointegration and error correction: Representation, estimation, and testing. Econometrica 55: 251-276.

Goldstein. M., and M. S. Khan. 1987. The supply and demand for exports: A simultaneous approach. Review of Economics and Statistics 60: 275-286.

1982. Effects of slow down in industrial countries a growth in non-oil developing countries. IMF Occasional Paper 12.

Houthhakker, H. S., and M. Stephen. 1969. Income and price elasticity's in world trade. The Review of Economics and Statistics 51: 111-125.

Johansen, S. 1991. Estimation and hypothesis testing of cointegration vectors in Gaussian vector autogressive model. Econometrica 59: 1551-1580.

Khan, M. S. 1974. Import and export demand in developing countries. IMF Staff Paper 21: $169-210$.

Marquez, J., and C. McNeilly. 1988. Income and price elasticity's for exports of developing countries. Review of Economics and Statistics 70: 306-314.

MacKinnon, J. G. 1991. Critical values for integration tests. In R. F. Egle \& C. W. J. Granger (Eds.): Long Run Economic Relationships: Reading in Co-Integration. Oxford: Oxford University Press.

Muscatelli, V. A. 1994. Demand and supply factors in the determination of NIE exports, a replay. Economics Journal 1014: 1415-1417.

Muscatelli, V. A., A. A. Stevense, and C. Montagna. 1995a. An analysis of the disaggregated manufacturing exports of the Asian NIEs to EEC, USA, and Japan. Applied Economics 27: 17-24.

Muscatelli, V.A. 1995b. Modelling aggregate manufactured export for some Asian newly industrialized economies. Review of Economics and Statistics 77: 147-155. 
Gadjah Mada International Journal of Business, May - August 2007, Vol. 9, No. 2

Mohamad H. A., and T. C. Tang. 2000. Aggregate imports and expenditure components in Malaysia: A cointegration and error correction analysis. Paper. Presented in Monash University, Malaysia. Internasional Symposium on Malaysia Business in the New Era.

O'neill, H. M., and W. Ross. 1991. Exchange rates and South Korea exports to OECD countries. Applied Economics 23: 1227-1236.

Pesaran, B. H., and B. Pesaran. 1997. Microfit: An Interactive Econometric Software Package (user manual). Oxford: Oxford University Press.

Philip, P. C. B., and M. Loretan. 1997. Estimating long-run economic equilibria. Review of Economic Studies 58: 407-436.

Riedel, J. 1984. Trade as the engine of growth in developing countries, recited. Economic Journal 94: 56-73.

1988. The demand for LDC exports of manufactures: Estimates from Hong Kong. The Economics Journal 98: 138-148.

1989. The demand for LCD exports of manufactures: Estimates from Hong Kong: A rejoinder. The Economic Journal 99: 467-470.

Saikkonen, P. 1991. Asymptotically efficient estimation of co-integration regressions. Econometric Theory 7: 1-21.

Tang T. C. 2003. Are imports and exports of the five ASEAN economies cointegrated? An empirical study. International Journal of Management 20 (1): 88-91. 